\title{
Its name is Legion
}

It is the staff of life when debates just run and run. Jenny Cheshire's article on masculine bias (ET 1, Jan 85 ) prompted comment well into the following year. Tony Fairman assailed grammarians (ET 17, Jan 89) for what he saw as prescriptivism behind the façade of objective description. That discussion of grammar and the standard language lasted for the rest of that year, and was transmuted in early 1990 into something wider still.

In our issue celebrating five completed years (ET21, Jan 90), Sir Randolph Quirk, in 'Language varieties and standard language', expressed concern about maintaining standards among the millions who use English. In due course, Braj Kachru sent us the first article of this issue: 'Liberation linguistics and the Quirk Concern.' These writers discuss fundamental matters. Is polarization occurring - between 'the standard bearers' on one side and the 'liberation linguists' on the other? We welcome further grist for this particular mill.

Parallel to the 'Quirk Concern' and the 'Kachru Reply' is the issue raised by Thomas Clayton, editor of the journal Cross Currents (Japan), first published as 'International Teaching of English to Speakers of Other Languages: Where Is Our Profession Going?' (CC, Fall 89). We reprinted this editorial (ET23, Jul 90) as 'Real and unreal teachers'. In this issue, P. D. Tripathi, an Indian national who works in Ethiopia, replies regarding who is any should be licensed to teach EFL. Further comment is planned for July.

Both the Quirk/Kachru and Clayton/Tripathi debates seem to have the same deep structure, which might be brought to the surface as Whose language is it anyway - and who lays down the law about it? I feel tempted immediately to rephrase the questions as Whose languages are they anyway - and who CAN lay down the law about them?, because the name of the demon of English in the late twentieth century appears to be Legion ('for we are many'). As Forthcoming shows (p. 64), July's ET will have four articles about the many: the English of New Zealand, Ghana, Pakistan, and Indonesia, all influenced by regional tongues and temperaments.

Meanwhile, Michelle Aldridge describes how every child meets the challenge of language afresh, and David Crystal shows how hard it can be to sustain the challenge through life. Martin Cutts asks lawyers to be as transparent as they can, in the name of Clear English, and Fraida Dubin, in looking at E-mail and BITNET, pursues the Word made, not flesh, but wire and plastic.

Tom McArthur

The editorial policy of English Today is to provide a focus or forum for all sorts of news and opinion from around the world. The points of view of individual writers are as a consequence their own, and do not reflect the opinion of the editorial board. In addition, wherever feasible, ET generally leaves unchanged the orthography (normally British or American) and the usage of individual contributors, although the editorial style of the journal itself is that of Cambridge University Press. 